\title{
Perilaku Merokok Remaja Sekolah Menengah Pertama
}

\author{
Smoking Behavior at Junior High School
}

\author{
Muhammad Rachmat, Ridwan Mochtar Thaha, Muhammad Syafar
}

\author{
Bagian Promosi Kesehatan dan Ilmu Perilaku Fakultas Kesehatan Masyarakat Universitas Hasanuddin
}

\begin{abstract}
Abstrak
Saat ini, perilaku merokok semakin merata, bukan hanya perilaku orang dewasa, tetapi juga telah menjadi gaya hidup para remaja. Penelitian ini bertujuan menilai hubungan antara tingkat pengetahuan, interaksi kelompok sebaya, interaksi keluarga, iklan rokok, dan sikap dengan perilaku merokok remaja di kota Makassar. Penelitian ini menggunakan desain studi observasional cross sectional. Teknik sampling menggunakan multistage random sampling dengan jumlah sampel 471 responden. Data dianalisis dengan uji kai kuadrat, koefisien phi (f) dengan $\alpha=0,05$. Responden perokok sekitar $25,3 \%$, sementara responden yang berpengetahuan rendah $16,6 \%$, berinteraksi negatif dengan kelompok sebaya $24,2 \%$, berinteraksi negatif dengan keluarga $47,8 \%$, respons negatif iklan rokok $4,9 \%$, dan sikap negatif $3,4 \%$. Uji kai kuadrat menunjukkan ada hubungan antara interaksi kelompok sebaya (nilai $p=0,000$ ), interaksi keluarga (nilai $p=0,010$ ), iklan rokok (nilai $p=0,000$ ), dan sikap merokok (nilai $p=0,001$ ) dengan perilaku merokok remaja. Tidak ada hubungan antara tingkat pengetahuan dengan perilaku merokok remaja (nilai $p=0,056$ ). Kelompok sebaya dan iklan rokok berpengaruh paling bermakna pada perilaku merokok remaja. Sekolah perlu dilibatkan lebih intensif pada upaya pencegahan dan intervensi perilaku merokok pada anak dan remaja.
\end{abstract}

Kata kunci: Iklan rokok, kelompok sebaya, perilaku merokok, remaja

\begin{abstract}
Nowadays, Smoking not only the behavior of adults, but it has become a way of life for most of teenagers. The study aimed to analyze the correlation between knowledge, peer group interaction, family interaction, cigarette advertisement, and attitude of smoking between smoking behavior among teenagers in Makassar city. Observational cross sectional study was performed in this study. There were 471 respondents selected by applying multistage random sampling. Data was analyzed with chi square test, phi coefficient (f) with $\alpha=0.05$. Number of smokers were $25.3 \%$ of respondents, meanwhile, low knowledge of respondents were $16.6 \%$, a negative
\end{abstract}

interaction within a peer group of $24.2 \%$, a negative interaction with family $47.8 \%$, the negative response to cigarette advertising $4.9 \%$, and a negative attitude $3.4 \%$. Chi square test showed there was a correlation between peer group interaction ( $p$ value $=0.000$ ), family interaction ( $p$ value $=0.010$ ), cigarette advertisement $(p$ value $=0.000)$, and smoking attitude $(p$ value $=$ $0,001)$, and smoking behavior of the teenagers. However, no correlation between the level of knowledge ( $p$ value $=0.056$ ) and smoking behavior among the teenagers. Peer group and cigarette advertisement most significant affect smoking behavior of teenagers. It is recommended that schools need to be involved to provide prevention and intervention on smoking behavior of teenagers are more intensive.

Keywords: Cigarette advertisement, peer group, smoking behavior, teenagers

\section{Pendahuluan}

Indonesia mengalami peningkatan terbesar perilaku merokok yang cenderung dimulai pada usia yang semakin muda. Pada usia $10-14$ tahun, terdapat $2,0 \%$ remaja yang merokok, $0,7 \%$ di antaranya merokok setiap hari dan 1,3\% perokok kadang-kadang dengan rerata konsumsi 10 batang rokok per hari. Proporsi penduduk menurut usia mulai merokok untuk kelompok usia muda (5 - 9 tahun) yang tertinggi adalah di Papua $(3,2 \%)$, sekitar 30 kali lebih besar dibandingkan dengan angka nasional $(0,1 \%)$. Sementara, di Sulawesi Selatan sekitar $0,8 \%$ atau 8 kali lebih besar dibandingkan dengan angka nasional. Untuk kelompok usia mulai merokok $10-14$ tahun, Sumatera Barat menduduki posisi tertinggi

Alamat Korespondensi: Muhammad Rachmat, Bagian Promosi Kesehatan dan Ilmu Perilaku FKM Universitas Hasanuddin, Jl. Perintis Kemerdekaan Km 10 Tamalanrea Makassar, Hp.085242458963,e-mail: rachmat.muh@gmail.com 
(13,6\%), sedangkan Sulawesi Selatan sekitar 10,0\%, lebih tinggi dibandingkan dengan angka nasional $(9,6 \%){ }^{1}$

Di Depok, sekitar 59,8\% remaja menyatakan pernah merokok. Di antara responden yang pernah merokok, sekitar 7,8\% menyatakan merokok pertama kali pada usia kurang dari 10 tahun, $34,4 \%$ pada usia $10-15$ tahun, $53,1 \%$ pada usia $16-20$ tahun, dan $4,7 \%$ pada usia lebih dari 20 tahun. Dari sekitar 59,8\% responden yang menyatakan pernah merokok, sekitar $81,3 \%$ masih merokok. ${ }^{2}$ Di Sulawesi Selatan, sekitar 2,2\% penduduk usia 10 - 14 tahun adalah perokok, 0,9\% di antaranya merokok setiap hari dan 1,3\% perokok kadang-kadang. Sekitar 1,4\% perokok usia $10-14$ tahun mulai merokok setiap hari pada usia 5 - 9 tahun dan 19,0\% mulai pada usia 10 - 14 tahun. Di Kota Makassar, sekitar 22,1\% penduduk saat ini merokok dengan rerata konsumsi 10,6 batang per hari. Dari jumlah perokok tersebut, sekitar $2,2 \%$ berusia $10-14$ tahun dengan rerata konsumsi rokok 5,2 batang per hari. Sekitar $0,8 \%$ mulai merokok tiap hari pada usia 5 - 9 tahun dan $7,7 \%$ pada usia $10-$ 14 tahun. Bahkan sekitar 2,6\% mulai merokok pada usia $5-9$ tahun. $^{3}$

Penelitian pada bulan Maret 2007, terhadap 278 siswa di suatu SMP Negeri di Makassar didapati 16,5\% siswa merokok, lebih dari dua pertiga responden adalah perokok reguler dan hanya sepertiga termasuk perokok coba-coba. Ada hubungan antara kelompok sebaya (nilai $\mathrm{p}=0,000, \mathrm{f}=0,752$ ), keluarga (nilai $\mathrm{p}=0,027, \mathrm{f}=$ 0,191 ), dan media massa (nilai $\mathrm{p}=0,000, \mathrm{f}=0,361$ ) dengan perilaku merokok remaja. ${ }^{4}$ Penelitian ini bertujuan mengetahui determinan perilaku merokok pada remaja.

\section{Metode}

Penelitian ini dilaksanakan pada bulan Februari - Mei tahun 2010 di Kota Makassar dengan mengambil sampel pada 13 SMP Negeri di 13 kecamatan. Jenis penelitian ini adalah observasional dengan menggunakan rancangan studi cross sectional. Variabel bebas terdiri dari tingkat pengetahuan, interaksi kelompok sebaya, interaksi keluarga, iklan rokok, dan sikap, sementara variabel terikat adalah perilaku merokok. Populasi penelitian ini adalah semua siswa SMP di Kota Makassar pada tahun ajaran 2009/2010 yang berjumlah 59.935 orang. Jumlah sampel sebanyak 471 orang. Metode pengambilan sampel adalah multistage random sampling. Data primer diperoleh melalui daftar kuesioner terstruktur yang dibagikan kepada seluruh siswa laki-laki yang hadir pada kelas terpilih setelah mendapat izin pengambilan data dari kepala sekolah. Responden diatur tempat duduknya layaknya sedang mengikuti ujian agar informasi yang diperoleh menggambarkan keadaan siswa yang sesungguhnya. Analisis data meliputi analisis univariat untuk melihat distribusi frekuensi masing-masing variabel yang diteliti. Analisis bivariat untuk melihat hubungan variabel bebas dengan variabel terikat dengan menggunakan uji kai kuadrat dan koefisien phi.

\section{Hasil}

Sekitar 25,3\% responden pernah merokok, sementara, responden berpengetahuan rendah sekitar 16,6\%, berinteraksi negatif dengan kelompok sekitar $24,2 \%$, berinteraksi negatif dengan keluarga sekitar $47,8 \%$, respons negatif iklan rokok sekitar 4,9\%, dan bersikap negatif sekitar 3,4\% (Tabel 1).

Responden berpengetahuan tinggi yang merokok adalah $27,0 \%$, lebih besar dari responden bepengetahuan rendah yang merokok $(16,7 \%)$. Responden yang berinteraksi kelompok sebaya negatif yang merokok adalah 53,5\%, tiga kali lebih besar dari responden yang berinteraksi kelompok sebaya positif yang merokok $(16,2 \%)$. Responden berinteraksi keluarga negatif yang merokok adalah 30,7\%, lebih besar dari responden yang berinteraksi keluarga positif yang merokok (20,3\%). Responden dengan respons negatif iklan rokok yang merokok adalah $65,2 \%$, hampir tiga kali lebih besar dari responden dengan respons positif iklan rokok yang merokok $(23,2 \%)$. Responden yang bersikap negatif yang merokok adalah $62,5 \%$, lebih besar dari responden yang bersikap positif yang merokok $(24,0 \%)$. Uji kai kuadrat menunjukkan hubungan antara interaksi kelompok sebaya (nilai $\mathrm{p}=0,000$ ), interaksi keluarga (nilai $\mathrm{p}=$ 0,010 ), iklan rokok (nilai $p=0,000$ ), dan sikap merokok (nilai $\mathrm{p}=0,001$ ) dengan perilaku merokok remaja. Tidak ada hubungan antara tingkat pengetahuan dengan perilaku merokok remaja (nilai $\mathrm{p}=0,056)($ Tabel 2$)$.

\section{Pembahasan}

Banyak alasan yang melatarbelakangi perilaku merokok remaja. Secara umum, perilaku merokok merupakan fungsi dari lingkungan dan individu. Artinya, perilaku merokok selain disebabkan faktor-faktor dari dalam diri juga disebabkan faktor lingkungan. Faktor dalam remaja dapat dilihat dari kajian perkembangan remaja yang mulai merokok berhubungan dengan krisis aspek psikososial yang dialami pada masa perkembangan, ketika mereka sedang mencari jati diri. Dalam masa remaja tersebut, sering dilukiskan sebagai masa badai dan topan

Tabel 1. Hasil Analisis Univariat Determinan Perilaku Merokok Remaja SMP

\begin{tabular}{llcc}
\hline Variabel & Kategori & Frekuensi & Persentase (\%) \\
\hline Merokok & Ya & 119 & 25,3 \\
Tingkat pengetahuan & Rendah & 78 & 16,6 \\
Interaksi kelompok sebaya & Negatif & 114 & 24,2 \\
Interaksi keluarga & Negatif & 225 & 47,8 \\
Iklan rokok & Negatif & 23 & 4,9 \\
Sikap & Negatif & 16 & 3,4 \\
\hline
\end{tabular}


Tabel 2. Hasil Analisis Bivariat Determinan Perilaku Merokok Remaja

\begin{tabular}{|c|c|c|c|c|c|c|c|}
\hline \multirow{3}{*}{ Variabel Independen } & \multirow{3}{*}{ Kategori } & \multicolumn{4}{|c|}{ Merokok } & \multirow{3}{*}{ Nilai $p$} & \multirow{3}{*}{ Nilai $\pi$} \\
\hline & & \multicolumn{2}{|c|}{ Tidak } & \multicolumn{2}{|c|}{ Ya } & & \\
\hline & & $\mathbf{n}$ & $\%$ & $\mathbf{n}$ & $\%$ & & \\
\hline \multirow[t]{2}{*}{ Tingkat pengetahuan } & Rendah & 65 & 83,3 & 13 & 16,7 & \multirow[t]{2}{*}{0,056} & \multirow[t]{2}{*}{0,088} \\
\hline & Tinggi & 287 & 73,0 & 106 & 27,0 & & \\
\hline \multirow[t]{2}{*}{ Interaksi kelompok sebaya } & Negatif & 53 & 46,5 & 61 & 53,5 & \multirow[t]{2}{*}{0,000} & \multirow[t]{2}{*}{0,367} \\
\hline & Positif & 299 & 83,8 & 58 & 16,2 & & \\
\hline \multirow[t]{2}{*}{ Interaksi keluarga } & Negatif & 156 & 69,3 & 69 & 30,7 & \multirow[t]{2}{*}{0,010} & \multirow[t]{2}{*}{0,119} \\
\hline & Positif & 196 & 79,7 & 50 & 20,3 & & \\
\hline \multirow[t]{2}{*}{ Iklan rokok } & Negatif & 8 & 34,8 & 15 & 65,2 & \multirow[t]{2}{*}{0,000} & \multirow[t]{2}{*}{0,208} \\
\hline & Positif & 344 & 76,8 & 104 & 23,2 & & \\
\hline \multirow[t]{2}{*}{ Sikap } & Negatif & 10 & 62,5 & 6 & 37,5 & \multirow[t]{2}{*}{0,001} & \multirow[t]{2}{*}{0,161} \\
\hline & Positif & 109 & 24,0 & 346 & 76,0 & & \\
\hline
\end{tabular}

karena ketidaksesuaian antara perkembangan psikis dan sosial. Upaya-upaya untuk menemukan jati diri tersebut, tidak semua dapat berjalan sesuai harapan masyarakat. Beberapa remaja melakukan perilaku merokok sebagai cara kompensatoris. Pada dasarnya perilaku merokok adalah perilaku yang dipelajari. Hal itu berarti ada pihakpihak yang berpengaruh besar dalam proses sosialisasi. ${ }^{5}$ Perilaku merokok biasanya dimulai pada masa remaja meskipun proses menjadi perokok telah dimulai sejak kanak-kanak. Masa remaja juga merupakan periode penting risiko untuk pengembangan perilaku merokok jangka panjang. Selain itu, perilaku merokok merupakan pintu masuk perilaku negatif yang lain seperti penyalahgunaan narkotika dan minum minuman keras.

\section{Tingkat Pengetahuan Remaja}

Pengetahuan merupakan faktor predisposisi yang memengaruhi perilaku seseorang, mereka yang berpengetahuan tinggi diharapkan berperilaku positif. Pada penelitian ini, pengetahuan tentang rokok bukan merupakan prediktor perilaku merokok pada perokok remaja. Pengetahuan mereka tentang merokok berada pada kategori tinggi $(83,4 \%)$. Hal tersebut sejalan dengan penelitian Chotidjah, 6 yang menemukan bahwa pengetahuan remaja tentang rokok pada kategori tinggi sebanyak $83,63 \%$.

Penelitian di Australia menemukan hampir semua responden (95\% mantan perokok, 90\% perokok, dan 97\% tidak pernah merokok) percaya bahwa merokok menyebabkan penyakit, sepertiga $(37 \%)$ perokok percaya merokok menyebabkan masalah kesehatan. Masalah kesehatan yang diidentifikasi oleh responden sebagai akibat merokok adalah kanker (tidak spesifik). Kanker merupakan penyakit yang paling umum disebut secara spontan (45\% mantan perokok, $52 \%$ perokok, dan $44 \%$ tidak pernah merokok), diikuti dengan penyakit jantung/ serangan jantung (25\% mantan perokok, $18 \%$ perokok dan $30 \%$ tidak pernah merokok). Kanker mulut diidentifikasi secara spontan hanya $2 \%$ responden. Penelitian tersebut menunjukkan responden cenderung setuju dengan pernyataan negatif seperti 'rokok adalah adiktif (94\%)', 'rokok mengandung zat-zat kimia yang toksik (97\%)', dan 'anak-anak akan berpotensi lebih besar untuk merokok jika orangtuanya merokok (71\%)', dan kurang pada pernyataan positif, 'jika seseorang tidak merokok itu adalah tanda-tanda kelemahan (9\%)', 'merokok adalah tanda-tanda kebijaksanaan $(10 \%)$ ', 'merokok menandakan bahwa anda macho $(12 \%)^{\prime}{ }^{7}$

Salah satu cara meningkatkan pengetahuan remaja dilakukan pelatihan pola pengasuhan anti-merokok. Sebuah studi dilakukan untuk menjelaskan pengaruh pelatihan pengasuhan anti merokok terhadap pengetahuan dan perilaku remaja terhadap merokok dengan menunjukkan pengaruh antara pengetahuan dan perilaku merokok. Pelaksanaan pengasuhan anti smoking diukur dengan reaksi orangtua terhadap merokok, aturan yang diterapkan di rumah, isi dan frekuensi komunikasi tentang merokok. Hubungan antara pelatihan dan tingkat pengetahuan hampir semuanya signifikan. Beberapa pelatihan kurang berhubungan dengan merokok seperti komunikasi tentang risiko kesehatan merokok, risiko gangguan sistem pernapasan karena merokok, penambahan kualitas rokok dan perhatian untuk merokok di sekolah. Faktor lain yang berhubungan dengan peningkatan kesempatan merokok antara lain meliputi hadiah untuk tidak merokok, frekuensi komunikasi tentang merokok, harga rokok, dan mempunyai teman yang merokok. Pengaruh pengasuhan sangat bervariasi berdasarkan status merokok orang tua atau gender yang dimiliki remaja. Beberapa pelatihan yang dijalankan lebih dititikberatkan untuk pengetahuan remaja yang beranjak dewasa. ${ }^{8}$

\section{Teman Sebaya Merokok}

Hasil penelitian menemukan sekitar $72,8 \%$ respon- 
den mempunyai teman merokok dalam kelompok sepermainan dan 51,0\% mempunyai teman akrab merokok. Sekitar 38,9\% responden pernah diajak merokok dan sekitar $29,5 \%$ pernah diberi rokok oleh teman akrab. Temuan ini sesuai dengan penelitian Chen, Huang \& Chao, ${ }^{9}$ bahwa remaja yang merokok mempunyai teman dekat yang juga merokok dan penelitian Iqbal, ${ }^{2}$ yang menemukan bahwa sebagian besar responden $(98,1 \%)$ mempunyai satu atau lebih teman yang berperilaku merokok. Sekitar 70,1\% responden pernah ditawarkan/diberi rokok oleh temannya. Hasil analisis bivariat menyimpulkan ada hubungan yang signifikan antara faktor teman (nilai $\mathrm{p}=0,033$ ) dengan perilaku merokok responden. Situasi dan kondisi yang sering mendorong mereka untuk merokok adalah saat bersama teman yang juga perokok.

Pengaruh teman sebaya terhadap perilaku merokok remaja sangat besar yang terbukti bahwa 54\% siswa pernah ditawari merokok oleh teman. ${ }^{10}$ Teman sebaya secara positif memengaruhi niat remaja merokok (nilai $p$ $=0,000)$ dan menjadi faktor yang paling dominan di antara variabel bebas yang lain. ${ }^{11}$ Kelompok sebaya merupakan sumber penting dari rokok pertama remaja. ${ }^{12}$ Dengan merujuk konsep transmisi perilaku, pada dasarnya perilaku dapat ditransmisikan melalui transmisi vertikal dan horisontal. Transmisi horisontal dilakukan oleh teman sebaya dalam hal ini lingkungan teman sebaya. Kebutuhan untuk diterima sering kali membuat remaja berbuat apa saja agar dapat diterima kelompoknya dan terbebas dari sebutan 'pengecut' dan 'banci'. ${ }^{5}$ Remaja mengalami tekanan internal untuk merokok jika orang lain di sekitar mereka merokok. Hasil penelitian lain menunjukkan status merokok sahabat, tekanan teman sebaya yang tinggi terkait dengan tahap merokok. ${ }^{13}$ Rokok digunakan untuk meningkatkan status sosial anak laki-laki di antara teman-teman mereka. Jika mereka merokok dengan 'baik', merek rokok mahal dan populer, mereka merasa lebih percaya diri, lebih dewasa, dan lebih kaya daripada rekan-rekan mereka. ${ }^{12}$

\section{Keluarga Merokok}

Keluarga berperan strategis membentuk sikap remaja merupakan sekolah dan tempat pembelajaran pertama seorang remaja. Orangtua merupakan teladan bagi anakanak, interaksi yang mendalam antara orang tua dan anak, melahirkan karakter yang mirip. Orangtua adalah model bagi seorang anak (remaja). Hasil penelitian menemukan sekitar $57,1 \%$ responden tinggal serumah dengan keluarga merokok, ayah dan kakak kandung dan $61,4 \%$ sering melihat mereka merokok. Sekitar 60,7\% responden mengaku pernah disuruh membeli rokok dan $56,7 \%$ responden pernah diajak merokok oleh keluarga. Remaja yang merokok mempunyai orangtua yang juga merokok dan penelitian Iqbal, 2 menemukan bahwa sekitar $75,7 \%$ responden mempunyai satu atau lebih anggota keluarga yang merokok, 24,3\% yang lain menyatakan bahwa satu atau lebih anggota keluarga tidak ada yang merokok. Di antara responden yang mempunyai anggota keluarga perokok, 90,1\% mempunyai ayah perokok, 8,6\% mempunyai ibu perokok, $42 \%$ mempunyai kakak perokok, dan 25,9\% mempunyai adik perokok. Namun, uji bivariat menunjukkan tidak ada hubungan yang signifikan antara faktor keluarga (nilai $\mathrm{p}$ $=0,715$ ) dengan perilaku merokok responden.

Transmisi vertikal perilaku dilakukan oleh orangtua berupa sikap permisif orangtua terhadap perilaku merokok. Orangtua atau saudara yang merokok merupakan agen imitasi yang baik. Jika keluarga tidak ada yang merokok, maka sikap permisif orangtua merupakan pengukuh positif atas perilaku merokok. Penelitian di Yogyakarta, menemukan sikap permisif orangtua terhadap perilaku merokok remaja merupakan prediktor perilaku merokok remaja $(38,4 \%) .{ }^{5}$ Penelitian di Kota Bogor, menemukan sekitar $60 \%$ siswa SMP mempunyai orangtua merokok. Risiko perokok pada siswa yang orangtua merokok adalah 2,44 kali lebih besar daripada siswa yang orangtuanya tidak merokok. ${ }^{10}$ Hasil penelitian lain menunjukkan jumlah yang lebih banyak dari kerabat yang merokok dan pemantauan orangtua terkait dengan tahap merokok. ${ }^{13}$ Data tersebut menegaskan peran penting rumah tangga dalam menginisiasi remaja merokok. Orangtua merokok dianggap sebagai bentuk legitimasi merokok bagi anak-anak mereka.

Orangtua merokok merupakan sumber penting kerentanan terhadap inisiasi merokok di kalangan remaja dan orangtua yang berhenti merokok menipiskan kerentanan tersebut. ${ }^{14}$ Penelitian lain menemukan prevalensi merokok yang berbeda pada remaja yang tinggal di rumah tangga yang mempunyai dan tidak mempunyai aturan larangan merokok. Hal tersebut menunjukkan dampak larangan merokok rumah tangga bagi para remaja yang tinggal dengan perokok $(\mathrm{OR}=1,55 ; 95 \% \mathrm{CI}$ $=1,21-1,99)$ dan yang tidak tinggal dengan perokok $(\mathrm{OR}=1,53 ; 95 \% \mathrm{CI}=1,26-2,22)$. Pada anak remaja, orangtua yang merokok berhubungan secara signifikan dengan risiko yang lebih tinggi permulaan merokok. Risiko permulaan merokok anak-anak dengan orangtua yang merokok meningkat sesuai dengan durasi mereka terpapar dengan orangtua yang merokok. Hal ini mendukung hubungan dosis-respons antara orangtua yang merokok dengan keturunan mereka yang merokok. Anak-anak dari orangtua yang telah berhenti merokok berisiko merokok lebih tinggi dibandingkan dengan anak-anak dengan orangtua yang tidak pernah merokok. Pengaruh orangtua yang merokok pada permulaan merokok keturunan mereka berbeda berdasarkan jenis kelamin, pengaruh lebih besar pada laki-laki dibandingkan wanita. Berdasarkan periode perkembangan, 
umur sebelum 13 tahun pengaruh lebih kuat dibandingkan dengan setelah umur tersebut. Berdasarkan tempat tinggal orangtua, pengaruh lebih besar jika tinggal di rumah yang sama. Orangtua yang merokok juga berhubungan dengan reaksi negatif yang lebih kuat terhadap remaja pada saat pertama kali mengisap rokok yang akan meningkatkan potensi risiko perkembangan merokok ke level yang lebih tinggi. ${ }^{15}$ Perilaku orang tua mendorong prilaku meniru seorang anak (remaja) terhadap orang tua. Remaja yang tinggal serumah dengan orang tua yang merokok dan sering melihat mereka merokok akan melakukan peniruan (imitasi) perilaku merokok. Orang tua menjadi model tingkah laku anakanak, termasuk perilaku merokok.

\section{Iklan Rokok}

Iklan rokok sebagai media promosi rokok dan berbagai jenis sangat potensial membentuk sikap dan perilaku merokok remaja. Pengetahuan tentang rokok banyak didapatkan melalui iklan rokok, baik jenis rokok terbaru maupun bahaya dari rokok itu sendiri. Hasil penelitian Chotidjah, ${ }^{6}$ menemukan bahwa sebagian besar responden $(93,63 \%)$ menyatakan bahwa mereka telah melihat iklan di pelayanan kesehatan masyarakat tentang pengaruh perilaku merokok dan televisi sebagai media informasi yang paling banyak diakses oleh mereka. Penelitian Martini dan Sulistyowati, 16 menemukan 87\% remaja terpapar iklan rokok di televisi, $75 \%$ terpapar melalui billboards, $42 \%$ melalui radio, dan $32 \%$ melalui surat kabar. Penelitian pada bulan Maret 2007 terhadap 278 siswa pada sebuah SMP Negeri di Makassar menunjukkan $15,2 \%$ remaja merokok karena pengaruh media massa dan 92,4\% responden sering melihat iklan rokok. ${ }^{4}$ Penelitian lain menunjukkan hampir seluruh responden $(93 \%)$ terpapar oleh iklan rokok di televisi. ${ }^{17}$

Penelitian di Jerman, pada tahun 2005 - 2006, terhadap 5.586 anak sekolah usia 10 - 17 tahun dengan rata-rata $12,8(\mathrm{SD}=1,2)$ menunjukkan $40,7 \%$ responden mencoba merokok, dan $12,3 \%$ adalah perokok saat ini. Sampel kuartil (Q) paparan merokok dalam film secara bermakna dikaitkan dengan prevalensi inisiasi merokok, yaitu 0,17 remaja pada Q1 telah mencoba merokok; 0,35 pada Q2; 0,47 pada Q3; dan 0,64 pada Q4. Paparan merokok dalam film secara bermakna dikaitkan dengan prevalensi merokok saat ini adalah 0,03 untuk remaja pada Q1; 0,08 pada Q2; 0,14 pada Q3; dan 0,25 pada Q4. Variabel yang dikontrol meliputi faktor sosial demografi, orangtua/teman/saudara merokok, kinerja sekolah, karakteristik kepribadian, konsumsi televisi, penerimaan untuk pemasaran tembakau dan gaya pengasuhan. ${ }^{18}$

Hasil penelitian lain pajanan iklan untuk rokok produk komersial terkait secara bermakna dengan perilaku merokok dibandingkan merek lain. Penelitian tersebut menggarisbawahi kekhususan hubungan antara pemasaran tembakau dengan perilaku merokok remaja serta paparan iklan rokok dikaitkan dengan perilaku merokok dan niat untuk merokok. ${ }^{19}$ Perhatian terhadap harga dan sikap pada iklan rokok secara signifikan berhubungan dengan merokok. Faktor 'hedonistik' berhubungan secara positif dengan status merokok dan variabel iklan. ${ }^{20}$ Media yang pro maupun anti tembakau bisa mempunyai efek tidak langsung yang signifikan pada perokok remaja melalui pengaruhnya pada normanorma yang ada pada suatu kelompok sebaya (peer). Pengaruh positif pada iklan pro rokok lebih besar daripada pengaruh negatif untuk anti iklan rokok. ${ }^{21}$ Bagi anak laki-laki, merokok dan iklan rokok memberikan konotasi positif, seperti 'hidup stabil', 'kesenangan', 'baik rasa', 'merasa begitu kaya', 'mengesankan', 'penampilan yang baik', dan 'menarik'. 12

\section{Sikap}

Sikap merupakan faktor personal yang berkaitan dengan perilaku, termasuk perilaku merokok. Sikap responden cenderung setuju dengan pernyataan positif seperti 'menghirup udara yang bebas dari asap rokok adalah hak asasi setiap orang sebanyak 72,9\%', 'menjauhi teman akrab merokok sebanyak 61,3\%', 'orangtua mewaspadai anaknya merokok sebanyak 85,6\%', dan 'iklan rokok perlu dibatasi sebanyak 77,3\%'. Sikap responden cenderung tidak setuju dengan pernyataan negatif yang mendukung perilaku merokok seperti 'asap rokok sama dengan asap biasa sebanyak 91,3\%', 'merokok bisa dimana saja sebanyak 78,8\%', 'bergaul dengan teman-teman perokok sebanyak 88,1\%', 'tinggal serumah dengan keluarga yang merokok sebanyak 74,1\%', 'ayah/kakak menyuruh anak/adiknya membeli rokok sebanyak 64,2\%', dan 'rokok disimpan sembarang tempat di rumah sebanyak 88,3\%'. Responden juga cenderung tidak setuju terhadap pernyataan seputar iklan rokok. Muatan gambar dan pesan iklan rokok yang cenderung mengajak merokok cenderung tidak disetujui responden, seperti 'perempuan sebagai bintang iklan rokok sebanyak 88,8\%', 'iklan rokok memberi kesan solidaritas pertemanan sebanyak 80,9\%', 'iklan rokok memberi kesan keren/macho sebanyak $80,5 \%$ ', 'iklan rokok memberi kesan mewah sebanyak $82,2 \%$, dan 'iklan rokok memberi kesan lebih dewasa sebanyak 69,9\%'. Hubungan yang signifikan dan positif antara sikap terhadap perilaku dan niat merokok remaja.

Remaja cenderung percaya bahwa merokok terlihat lebih gaul dan matang, serta merasa dapat diterima teman-teman. ${ }^{11}$ Remaja yang sekolah di kawasan tanpa rokok (KTR) berpeluang 3,2 kali lebih tinggi untuk bersikap positif dan 2,6 kali lebih tinggi untuk berhenti merokok dibandingkan remaja sekolah tidak KTR. ${ }^{22}$ Hanya $57 \%$ responden bersikap positif terhadap perilaku merokok. ${ }^{17}$ Ada hubungan bermakna antara sikap dan 
perilaku merokok pada pelajar SMP di Surakarta. ${ }^{23}$

\section{Kesimpulan}

Hasil penelitian menunjukkan ada hubungan antara interaksi kelompok sebaya, interaksi keluarga, iklan rokok, dan sikap dengan perilaku merokok remaja. Tidak ada hubungan antara tingkat pengetahuan dengan perilaku merokok remaja. Kelompok sebaya dan iklan rokok paling bermakna dalam memengaruhi perilaku merokok remaja.

\section{Saran}

Sekolah perlu dilibatkan dalam upaya mencegah dan mengintervensi perilaku merokok pada anak dan remaja secara lebih intensif. Orangtua yang menginginkan anaknya tidak merokok perlu waspada terhadap kelompok sebaya anak-anak, anggota keluarga tidak disarankan merokok atau tidak memberikan pengukuhan positif ketika remaja merokok dan pemerintah membuat regulasi yang membatasi distribusi rokok dan usia konsumen yang boleh membeli serta iklan-iklan rokok yang beredar di masyarakat untuk meminimalkan kemungkinan anakanak dan remaja untuk menjadi konsumen rokok.

\section{Daftar Pustaka}

1. Departemen Kesehatan Republik Indonesia. Riset kesehatan dasar (Riskesdas) 2007 nasional. Jakarta: Departemen Kesehatan Republik Indonesia; 2008.

2. Iqbal MF. Perilaku merokok remaja di lingkungan RW 22 Kelurahan Sukatani Kecamatan Cimanggis Depok tahun 2008 [online]. 2008 [diakses tanggal 12 Februari 2012]. Diunduh dalam: http://www.digilib.ui.ac.id//opac/themes/libri2/detail.jsp?id=123594\&lokasi=lokal.

3. Departemen Kesehatan Republik Indonesia. Riset kesehatan dasar (Riskesdas) 2007 Provinsi Sulawesi Selatan. Jakarta: Departemen Kesehatan Republik Indonesia; 2008.

4. Rachmat M. Studi perilaku merokok remaja pada SMP Negeri 8 Makassar tahun 2007 [skripsi]. Makassar: Fakultas Kesehatan Masyarakat Universitas Hasanuddin; 2007.

5. Komalasari D, Fadilla HA. Faktor-faktor penyebab perilaku merokok remaja [diakses tanggal 23 Juli 2009]. Diunduh dalam: http://avin.staff.ugm.ac.id/data/jurnal/perilakumerokok_avin.pdf.

6. Chotidjah S Pengetahuan tentang rokok, pusat kendali kesehatan eksternal dan perilaku merokok. Makara Sosial Humaniora. 2012; 16 (1): $49-56$.

7. Ramos V, Germain D, Ross N. Smoking behaviour, knowledge and attitudes among the spanish speaking community in Victoria, Australia [manuscript on the internet]. 2009 [cited 2010 Apr 2]. Available from: http://www.quit.org.au/downloads/NESB/Spanish_Smoking_Survey.pdf.

8. Huver RM, Engels RC, de Vries H. Are anti-smoking parenting practices related to adolescent smoking cognitions adn behavior? Health Edu Res [serial on the internet]. 2006; 21(1): 66-7 [cited 2008 Jun 5]. Available from: http://her.oxfordjournals.org/cgi/reprint/21/1/66.

9. Chen PL, Huang WG, Chao KY. Susceptibility to initiate smoking among junior and senior high school non-smokers in Taiwan. Prev Med [serial on the internet]. 2009; 49: 58-61 [cited 2010 Apr 2]. Available from: http://10.1016/j.ypmed.2009.04.013.

10. Purnawanti RY. Hubungan antara perilaku merokok orang tua dengan perilaku merokok remaja siswa SMP di Kota Bogor tahun 2007 [tesis]. Depok: Universitas Indonesia; 2008.

11. Virdiana R, Anas H. Smoking behavior studi on teenagers' (online). Jurnal Siasat Bisnis [online]. 2009; 13 (1): 61-76 [diakses tanggal 3 April 2013]. Available from: http:// fecon. uii.ac.id/ images/ stories/ jurnal/ JSB/ apri109/7_virdi-anas\%20untuk\%20agustus\%202009\%20revised.pdf.

12. Ng N, Weinehall L, Öhman A. If I don't smoke, I'm not a real man 'Indonesian teenage boys' views about smoking. Health Ed Res [serial on the internet]. 2007; 22 (6): 794-804 [cited 2010 Jan 6]. Available from: http://her.oxfordjournals.org/content/22/6/794.full.pdf+html.

13. Jeganathan PD, Hairi NN, Al Sadat N, Chinna K. Smoking stage relations to peer, school and parental factors among secondary school students in Kinta, Perak. Asian Pac J Cancer Prev [serial on the internet]. 2013; 14: 3483-9 [cited 2013 Sep 3]. Available from: http:// www. apocpcontrol. org/ paper_file/issue_abs/ Volume14_No6/ 3483-9\% 203.8\% 20 Premila \% 20 Devi \% 20 Jeganathan.pdf.

14. Gilman SE, Rende R, Boergers J, Abrams DB, Buka SL, Clark M, et al. Parental smoking and adolescent smoking initiation: an intergenerational perspective on tobacco control. Pediatrics [serial on the internet]. 2009; 123: e274-e281 [cited 2010 Jan 6]. Available from: http://pediatrics.aappublications.org/content/123/2/e274.full.pdf+html

15. Albers AB, Biener L, Siegel M, Cheng DM, Rigotti N. Household smoking bans and adolescent antismoking attitudes and smoking initiation: findings from a longitudinal study of a Massachusetts Youth Cohort. Am J Publ Health [serial on the internet]. 2008; 98 (10): 1886-93 [cited 2010 Apr 1]. Available from: http://ajph.aphapublications.org/cgi/reprint/98/10/1886.

16. Martini S, Sulistyowati M. The determinants of smoking behavior among teenagers in East Java Province, Indonesia. Eco Tobacco Control Paper [serial on the internet]. 2005; 32 [cited 2010 Jan 1]. Available from: http:// siteresources. worldbank.org/ HEALTHNUTRITIONANDPOPULATION/ Resources/ 2816271095698140167/ IndonesiaYouthSmokingFinal.pdf.

17. Kurniasih A. Faktor-faktor yang berhubungan dengan perilaku merokok siswa SLTP di Bekasi tahun 2008 [skripsi]. Depok: Universitas Indonesia; 2008.

18. Hanewinkel R, Sargent JD. Exposure to smoking in popular contemporary Movies and Youth Smoking in Germany. Am J Prev Med [serial on the internet]. 2007; 32(6): 466-73 [cited 2010 Apr 1]. Available from: http://www.ncbi.nlm.nih.gov/pmc/articles/PMC1963468/pdf/nihms25 373.pdf.

19. Hanewinkel R, Isensee B, Sargent JD, Morgenstern M. Cigarette advertising and adolescent smoking. Am J Prev Med [serial on the internet]. 2010; 38(4): 359-366 [cited 2013 Sep 3]. Available from: http://www.ncbi.nlm.nih.gov/pubmed/20307803.

20. Chang C. Personal values, advertising, and smoking motivation in taiwanese adolescent. Journal of Health Communication [Influence of Tobacco Marketing on Smoking Behavior, Monograph 19]. 2010; 10 (7): 621-34 [cited 2010 Apr 5]. Available from: http://cancercontrol. 
cancer.gov/ tcrb/ monographs/ 19/ m19_complete.pdf.

21. Gunther AC, Bolt D, Borzekowski DLG, Liebhart JL, Diliar JP. Presumed influence on peer norms: how mass media indirectly affect adolescent smoking. Journal of Communication [Influence of Tobacco Marketing on Smoking Behavior, Monograph 19. The Role of the Media]. 2006; 56 (1): 52 - 68 [cited 2010 Apr 1]. Available from: http:// cancercontrol. cancer.gov/ tcrb/ monographs/ 19/ m19_complete.pdf.
22. Nurkania N. Pengaruh penerapan kawasan tanpa rokok di sekolah terhadap sikap dan perilaku berhenti merokok siswa SMA di Kota Bogor [tesis]. Yogyakarta: Universitas Gadjah Mada; 2007.

23. Hasan A. Pengetahuan, sikap, dan perilaku merokok pelajar SMP di Kota Surakarta [tesis]. Jakarta: Fakultas Kedokteran Universitas Indonesia; 2005 [diakses tanggal 20 Februari 2010]. Diunduh dalam: http://www.digilib.ui.ac.id//opac/themes/libri2/detail.jsp?id=107828\& lokasi=lokal. 